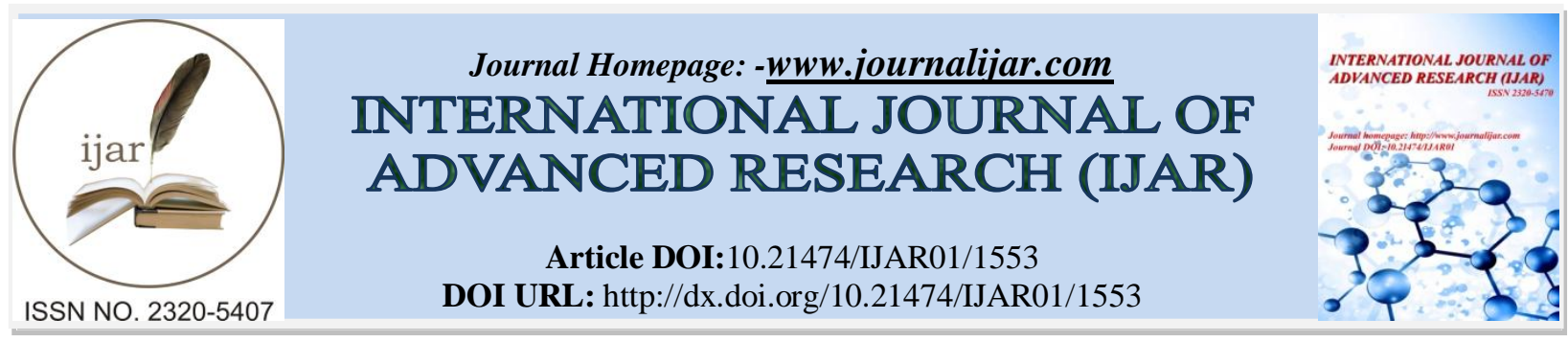

RESEARCH ARTICLE

\title{
STUDY OF CULTURABLE MICROBIAL COUNTS AND ITS RELATION WITH VARIOUS SOIL PARAMETERS NEAR LALPARILAKE, RAJKOT.
}

\author{
V. B. Pattani ${ }^{1}$, Jinesh P. Kaneriya ${ }^{1}$, Goral G. Boda ${ }^{1}$ and Atul G. Makasana ${ }^{2}$. \\ 1. Shree H. N. Shukla College of Science, Nr. Lalpari Lake, B/h Marketing Yard, Rajkot-360 003. \\ 2. Sarvopari Science College, Morbi 363641.
}

\section{Manuscript Info}

Manuscript History

Received: 14 July 2016

Final Accepted: 22 August 2016

Published: September 2016

Key words:-

Phosphate solubilizers, organic carbon, total nitrogen, phosphorus, potassium

\section{Abstract}

Soil is an important component of the earth's system, functioning not only for the production of food, fodder and fibre but also in the maintenance of local and regional environmental quality. In the present study attempt has been made to study culturable bacteria in soil and its relation with soil parameters such as electrical conductivity, $\mathrm{pH}$, and percentage of organic compound and total nitrogen, phosphorus, sulphur, calcium, magnesium and potassium. Soil samples were found to be of neutral $\mathrm{pH}$, low salinity, high nitrogen, low organic carbon, range of phosphorus and potassium from medium to high. Site LP2 showed maximum number of bacterial colonies. Potassium content in soil was found to be high.

Copy Right, IJAR, 2016,. All rights reserved.

\section{Introduction:-}

In the age of modern science it is necessary to know the basic needs of soil. Healthy soil is basic component of the modern and scientific tillage so that it is necessary to require the basic needs of soil.Soil is a reservoir of nutrients required by crops, but not necessarily at optimum levels of immediate availability to plants. Soil fertility is an important factors and which determine by presence or absence of soil parameters namely $\mathrm{pH}, \mathrm{EC}, \mathrm{C}, \mathrm{N}, \mathrm{P}, \mathrm{K}, \mathrm{Ca}$, $\mathrm{Mg}$, and S. Application of statistical tools can provide such information and assist the interpretation of soil tested data[1]. Growth of plant is determined through soil fertility and soil fertility is determined by the availability of macro and micronutrients and other minerals and nutrients. Formation of soil is a biogeochemical process that is dependent on the materials deposited and degraded by microorganisms on the uppers soil layer. These processes are developed a long time and space, and have as final product the formation of soils with different physical and chemical characteristics. Different soil microorganisms, control of ecosystem functioning through decomposition and nutrient availability and may serve as indicators of land-use change and ecosystem health [2]. However, the study of soil microorganisms is difficult and our current understanding limited. The variety and small size of these groups become more specious as our skills to explore them have improved in recent years [3]the soil microbial populations are vibrant and various[4] almost beyond measure[5], and that some patterns seem to hold on a global scale.The type of flora cover and dominant species of forest ecosystems affects the chemical, biological and biochemical properties of soils[6]. Due to the accumulation of organic residue, a significant proportion of the nutrients extracted from soil are retained by plants, and the breakdown of plant residue releases nutrients, which can be reused by flora and microorganisms [7].

The focus of this paper is to study classification of soil samples according to their properties by using descriptive statistical analysis. To determine the relationship between $\mathrm{pH}, \mathrm{EC}$ and macro nutrients $(\mathrm{P}, \mathrm{K}, \mathrm{C}$ and $\mathrm{S}$, total $\mathrm{N}$,) and 
Microbial analysis of soil such as total viable bacterial, fungal and Actinomycetes In the present study to made in situ features of bacteria and counts of bacteria and its connection with different physiochemical and microbial parameters of soil

\section{Material \& Methods:-}

Soil samples:-

Soil samples collected from different area around Lalparilake of Rajkot, Gujarat. From each sampling point 3 samples of soil were collected form each nine sites and each nine sites were divided into three different areas designated as LP1, LP2 and LP3. The soil around the root was carefully dug up to $30 \mathrm{~cm}$ depth collected and transferred into polythene bags. The soil samples were stored in refrigerator till further use.

\section{Enumeration of microbes:-}

Samples of soil were plated on nutrient agar, potato dextrose agar and starch casein agar with different dilution using spread plated technique to enumerate bacteria, fungi and Actinomycetes respectively. Colonies were counted at 24 hours interval until 72 hours and colony forming unit per gram was calculated for each sample.

pH and electrical conductivity $(\mathrm{EC}, \mathrm{dS} / \mathrm{m})$ were determined in the supernatant solution of 1:5 soil/water ratio (w/v) using a $\mathrm{pH}$ meter and conductivity bridge / meter respectively.

Organic carbon was determined by the wet digestion method of Walkley and Black [8].

Nitrogen, Potassium and Phosphorus were determined by Jones[9].

Sulphurwas determined by Zhao et al., 1996[10].

Calcium and Magnesium were determined by Rowell (2014)[11].

Interpretation of all the physical and chemical properties of soilwere done according to Methods ManualSoil Testing in India[12].

All the statistical calculation were done using Microsoft Office Excel (2013) and XLSTAT- PRO 7.5.

\section{Result and Discussion:-}

Enumeration:-

Colony forming unit per gram was calculated by counting bacterial colonies on Nutrient agar plates, potato dextrose agar plate and starch casein agar.

Table 1:-Colony forming unit per gram of soil.

\begin{tabular}{|c|c|c|c|}
\hline Sample & Total bacterial Count & Total fungal Count & Actinomycetes \\
\hline LP1 & $3.0 \times 10^{11}$ & $4.0 \times 10^{5}$ & $2.0 \times 10^{6}$ \\
\hline LP2 & $1.3 \times 10^{12}$ & $3.0 \times 10^{4}$ & $1.0 \times 10^{4}$ \\
\hline LP3 & $4.0 \times 10^{9}$ & $8 \times 10^{3}$ & $1.0 \times 10^{6}$ \\
\hline
\end{tabular}

\section{pH and Electrical Conductivity:-}

The measure of soil $\mathrm{pH}$ is an important parameter which helps in identification of chemical nature of the soil[13] as it measures hydrogen ion concentration in the soil to indicate it's acidic and alkaline nature of the soil.pH of the samples was found to be between 7 and 8.1(Table 2)indicating the existence of a variety of soils that are moderately alkaline nature.

Conductivity $(\mathrm{dS} / \mathrm{m})$, as the measure of current carrying capacity, gives a clear idea of the soluble salts present in the soil. It plays a major role in the salinity of soils. Lesser the EC value, low will be the salinity value of soil and vice versa. Conductivity $(\mathrm{dS} / \mathrm{m})$ was found to be low at all the sites indicating low salinity. Even though, soil conductivity is influenced by many factors, high conductivities are usually associated with clay-rich soil and low conductivities are associated with sandy and gravelly soils. This is a result of the shape and physical properties of the particles which make up the soil. There are various factors that affect the soil electrical conductivity such as pore continuity, water content, salinity level, cation exchangecapacity, depth and temperature [14]. 
Table 2:-Selected Physical and Chemical Properties of soil.

\begin{tabular}{|c|c|ccc|ccc|ccc|}
\hline \multicolumn{1}{|c|}{ Parameters } & \multicolumn{9}{|c|}{ Sites } \\
\hline & UNITS & \multicolumn{3}{|c|}{$\mathrm{A}$} & \multicolumn{3}{c|}{$\mathrm{B}$} & \multicolumn{3}{c|}{$\mathrm{C}$} \\
\hline $\mathrm{pH}$ & & 7.99 & \pm & 0.01 & 7.43 & \pm & 0.01 & 8.05 & \pm & 0.03 \\
\hline $\mathrm{E} . \mathrm{C}$ & $\mathrm{d} / \mathrm{m}$ & 0.57 & \pm & 0.00 & 1.93 & \pm & 0.00 & 0.41 & \pm & 0.01 \\
\hline $\mathrm{OC}$ & $\%$ & 1.07 & \pm & 0.00 & 0.16 & \pm & 0.00 & 0.95 & \pm & 0.01 \\
\hline $\mathrm{TN}$ & $\mathrm{Kg} / \mathrm{ha}$ & 234.87 & \pm & 2.61 & 245.93 & \pm & 1.77 & 262.44 & \pm & 2.74 \\
\hline $\mathrm{OM}$ & $\%$ & 1.83 & \pm & 0.01 & 0.27 & \pm & 0.01 & 1.64 & \pm & 0.01 \\
\hline $\mathrm{K}$ & $\mathrm{Kg} / \mathrm{ha}$ & 884.69 & \pm & 7.61 & 1170.05 & \pm & 11.27 & 405.03 & \pm & 3.12 \\
\hline $\mathrm{P}$ & $\mathrm{Kg} / \mathrm{ha}$ & 6.95 & \pm & 0.03 & 6.23 & \pm & 0.03 & 20.18 & \pm & 0.03 \\
\hline $\mathrm{S}$ & $\mathrm{ppm}$ & 208.71 & \pm & 1.52 & 268.50 & \pm & 1.26 & 115.06 & \pm & 1.44 \\
\hline $\mathrm{Ca}$ & $\%$ & 0.61 & \pm & 0.01 & 0.32 & \pm & 0.00 & 0.53 & \pm & 0.01 \\
\hline $\mathrm{Mg}$ & $\%$ & 0.24 & \pm & 0.00 & 0.04 & \pm & 0.00 & 0.23 & \pm & 0.00 \\
\hline
\end{tabular}

\section{Percentage Organic carbon $(\mathrm{OC})$ and percent organic Matter (OM)}

The importance of organic matter in the soil is implied in the definition of soil, which recognizes fertility status of the soil, as a unique feature distinguishing soil from the parent rock/ other non-fertile soils. It increases the soil fertility / nutrient status and controls erosion and runoff of the soil and water, besides it is a major determinant of improved soil structure, moisture content and general nutrient status of the soil. The percentage of organic carbon ranged from 0.16 to 1.07 (Table 2)and percentage of organic matter was found to be in range of 0.27 to 1.84 (Table 2) in the study area. Depending upon theorganic carbon content (\%), the quality of soil was found to be low to high. Soils with low carbon are due to good aeration which increase the oxidation of organic matter present in the soil[15].

\section{Phosphorus:-}

Phosphorus is the second most important macronutrient available in the biological systems, which constitutes more than $1 \%$ of the dry organic weight. It is also a second most limiting factor often affecting plant growth, which exists in the soil in both organic and inorganic forms[16]. The phosphorus $(\mathrm{kg} / \mathrm{ha})$ was found in range of 6.9 to 20.18 $\mathrm{kg} / \mathrm{ha}$ (Table 2). Phosphorus content was found to be low to medium.

\section{Nitrogen:-}

Plants take up nitrogen generally as nitrates under aerobic conditions and as ammonium ions during anaerobic conditions. Nitrogen is most often the limiting nutrient for the plant growth[17]. The percentage of total nitrogen was found in range of $234 \mathrm{~kg} / \mathrm{ha}$ to $264 \mathrm{~kg} / \mathrm{ha}$ (Table 2). Total nitrogen content was found to be high.

\section{Potassium (K):-}

Next to nitrogen and phosphorous, potassium is the most critical essential element in influencing plant growth and production throughout the world. Potassium plays essential role in plants. It is an activator for dozens of enzymes responsible for plant process[18]. The Potassium (K) (kg/ha) values varied from 405to $1170 \mathrm{~kg} / \mathrm{ha}$ (Table 2). Potassium in soil samples ranged to be very high.

\section{Sulphur:-}

The form of sulfur taken up by plants is sulfate-sulfur and must be constantly replenished. Sulfur from all sources must either be in the sulfate form or be converted to the sulfate form before it can be used by plants[19].Sulphur content in soil was found to be in range of 115 to $268 \mathrm{ppm}$ (Table 2).

\section{Calcium:-}

A soil with the appropriate amount of Calcium will remain loose and workable. Calcium is the major transporter of other minerals and nutrients, including sugars[20]. Calcium content in the soil was found to be in the range 0.32 to 0.61(Table 2).

\section{Magnesium:-}

Magnesium is a component of several primary and secondary minerals in the soil, which are essentially insoluble, for agricultural considerations. These materials are the original sources of the soluble or available forms of $\mathrm{Mg}$. Magnesium is also present in relatively soluble forms, and is found in ionic form $\left(\mathrm{Mg}^{++}\right)$adhered to the soil colloidal 
complex[21]. The ionic form is considered to be available to crops. Magnesium content in the soil was found to be in the range 0.04 to 0.23 (Table 2)

\section{Relation among soil parameters:-}

Correlation matrix is given in Table 3. Correlation studies of electrical conductivity with $\mathrm{pH}$, potassium, percent organic carbon, percent organic matter, phosphorus and percent total nitrogen was found to be negative and with that of sulphur and magnesium was found to be positive. $\mathrm{pH}$ was negatively correlated with potassium, sulphur and electrical conductivity and positively correlated with other parameters. Phosphorus and potassium show strong relationship with each other.Organic carbon showed strong relationship with $\mathrm{pH}$ and less correlated with the other parameters. Nitrogen showed positive correlation with phosphorus and magnesium.

Table 3:-Matrix correlations among different soil properties in tabular form.

\begin{tabular}{|c|c|c|c|c|c|c|c|c|c|c|}
\hline & $\mathrm{pH}$ & $\mathrm{E} . \mathrm{C}$ & $\mathrm{OC}$ & $\mathrm{TN}$ & $\mathrm{OM}$ & $\mathrm{K}$ & $\mathrm{P}$ & $\mathrm{S}$ & $\mathrm{Ca}$ & $\mathrm{Mg}$ \\
\hline $\mathrm{pH}$ & 1.000 & & & & & & & & & \\
\hline E.C & -0.995 & 1.000 & & & & & & & & \\
\hline OC & 0.975 & -0.978 & 1.000 & & & & & & & \\
\hline TN & 0.214 & -0.196 & 0.003 & 1.000 & & & & & & \\
\hline OM & 0.975 & -0.978 & 1.000 & 0.003 & 1.000 & & & & & \\
\hline $\mathrm{K}$ & -0.054 & -0.002 & -0.007 & -0.148 & -0.007 & 1.000 & & & & \\
\hline $\mathrm{P}$ & 0.064 & 0.001 & 0.009 & 0.231 & 0.009 & -0.945 & 1.000 & & & \\
\hline $\mathrm{S}$ & -0.068 & 0.014 & -0.019 & -0.161 & -0.019 & 0.998 & -0.939 & 1.000 & & \\
\hline $\mathrm{Ca}$ & 0.021 & -0.014 & 0.002 & -0.070 & 0.002 & -0.575 & 0.277 & -0.587 & 1.000 & \\
\hline $\mathrm{Mg}$ & 0.002 & 0.019 & -0.032 & 0.016 & -0.032 & -0.764 & 0.514 & -0.777 & 0.962 & 1.000 \\
\hline
\end{tabular}

Relation of Bacteria with soil parameters:-

In the present study $\mathrm{pH}$ was found to be neutral to slightly alkaline which is an indication that population of bacteria were high as compared to acidic $\mathrm{pH}$ soils[22]. In the given study $\mathrm{pH}$ at site LP2 was neutral and maximum bacteria population was found at the same site. Electrical conductivity was found to be less than $2 \mathrm{dS} / \mathrm{m}$ indicating low saline and supporting growth of bacteria, increase in $>2 \mathrm{dS} / \mathrm{m}$ will have negative impact on respiration, decomposition, nitrification and denitrification[23]. Soil organic carbon is the major source of energy for the soil microorganisms and Organic Carbon reaches its optimum value when the soil $\mathrm{pH}$ is in between 5.00 to 6.00 and decreases when lower than 5.00[24]. Nitrogen addition in temperate forests typically increases microbial biomass at a short term basis [25] but over the longer term, biomass generally decreases [26]. Total Nitrogen was found to be high and has negative impact over nitrification process. The organisms involved in phosphorus $(\mathrm{P})$ cycling in soils are highly varied, and microorganisms probably play the most important role. Till date $99 \%$ of soil microorganisms have not been cultured successfully[27]. Microorganisms play an important role in all three major components of the soil P cycle i.e. dissolution, precipitation, adsorption, desorption, mineralization and immobilization. Excess potassium leads to decrease in count of bacteria in soil. 

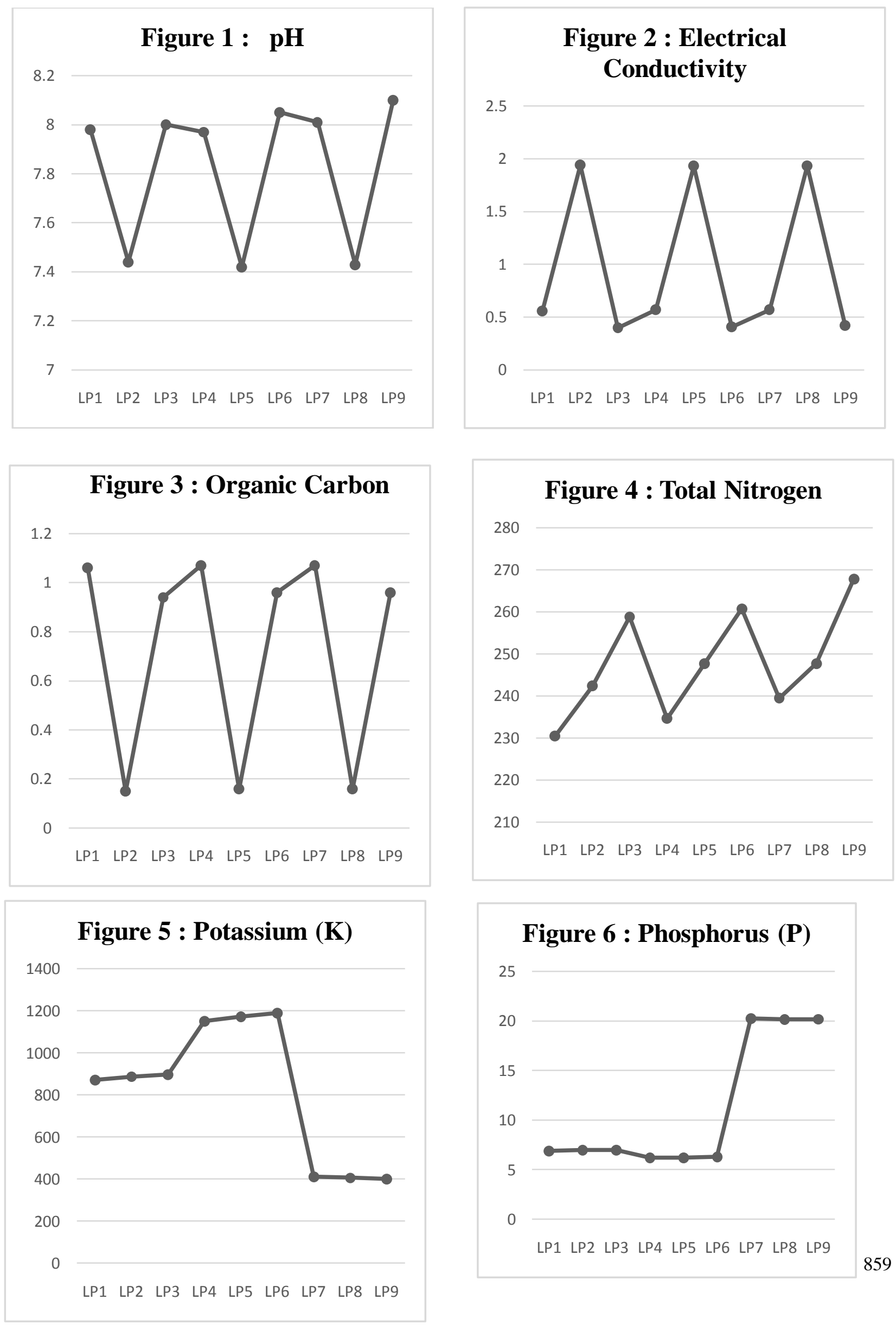

\section{Figure 6 : Phosphorus (P)}

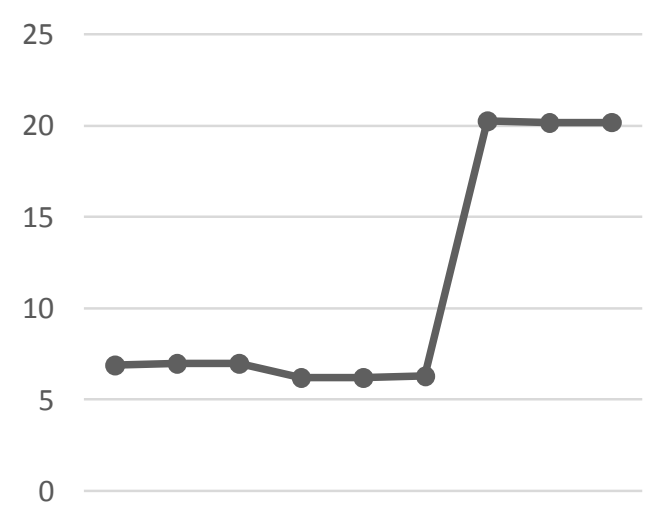

LP1 LP2 LP3 LP4 LP5 LP6 LP7 LP8 LP9 

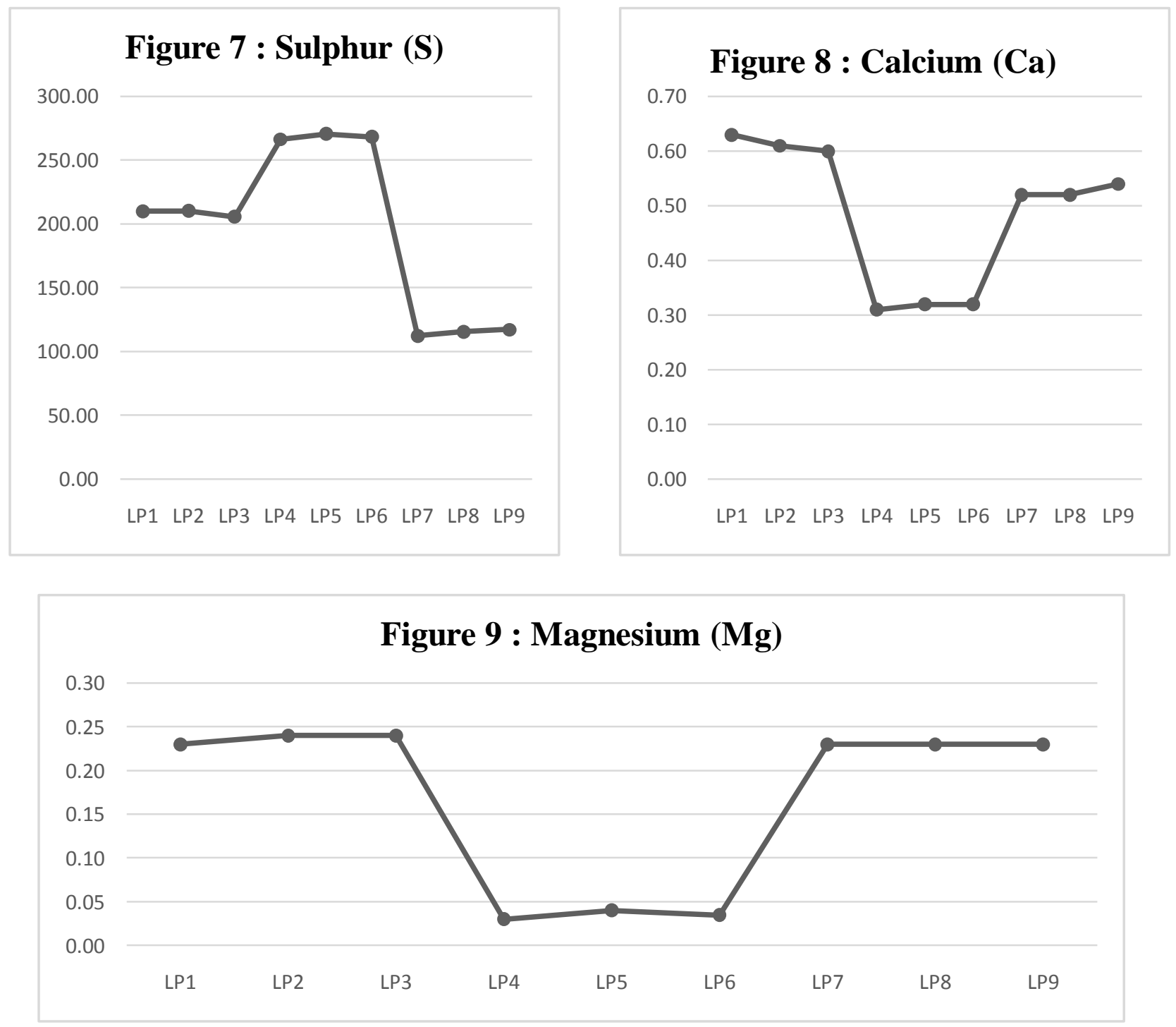


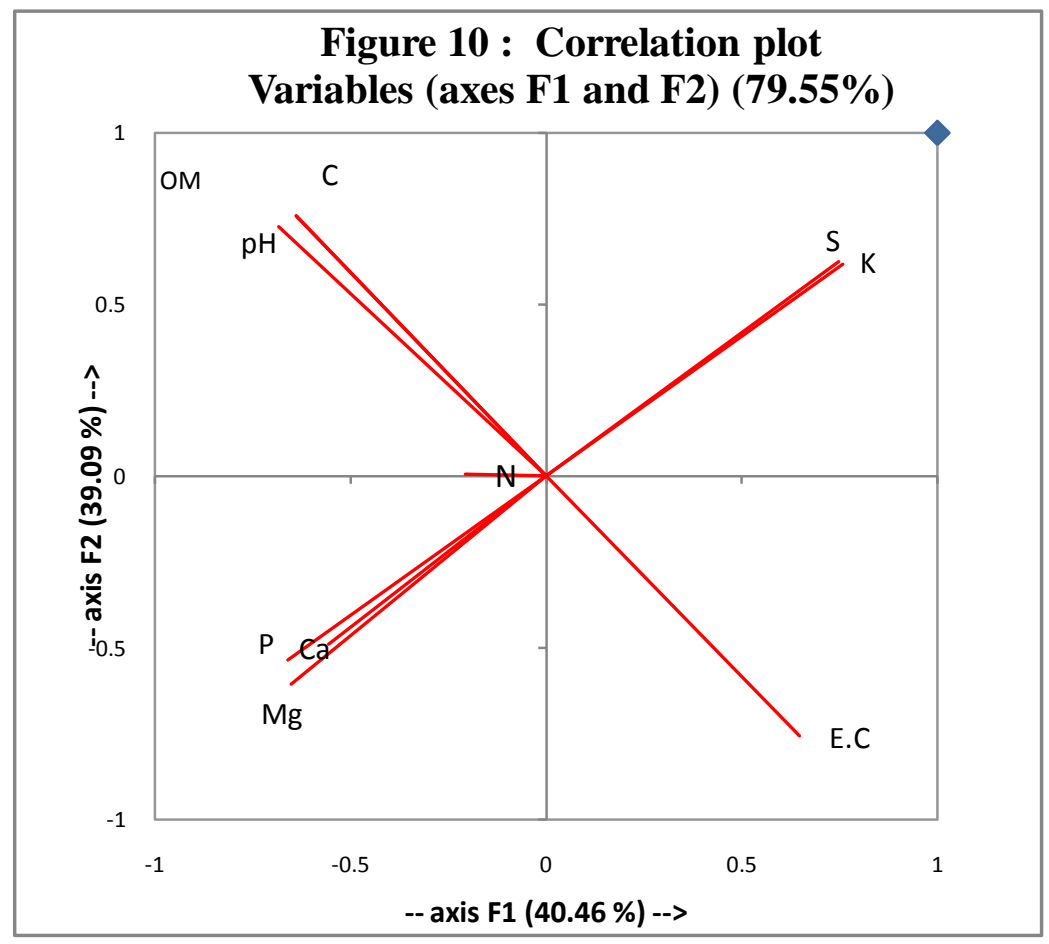

\section{References:-}

1. Patel, P.L., et al., Study of Basic Soil Properties in Relation with Micronutrients of Mandvi Tahsil near Coastal Region of Kutch District. International Journal of Science and Research (IJSR), 2014. 3(6): p. 25-28.

2. Yao, H., et al., Microbial biomass and community structure in a sequence of soils with increasing fertility and changing land use. Microbial Ecology, 2000. 40(3): p. 223-237.

3. Cardon, Z.G. and D.J. Gage, Resource exchange in the rhizosphere: molecular tools and the microbial perspective. Annual review of ecology, evolution, and systematics, 2006: p. 459-488.

4. Al Agely, A., D.M. Sylvia, and L.Q. Ma, Mycorrhizae Increase Arsenic Uptake by the Hyperaccumulator Chinese Brake Fern (L.). Journal of environmental quality, 2005. 34(6): p. 2181-2186.

5. Schloss, P.D. and J. Handelsman, Introducing SONS, a tool for operational taxonomic unit-based comparisons of microbial community memberships and structures. Applied and environmental microbiology, 2006. 72(10): p. 6773-6779.

6. Priha, O., et al., Microbial community structure and characteristics of the organic matter in soils under Pinus sylvestris, Picea abies and Betula pendula at two forest sites. Biology and Fertility of Soils, 2001. 33(1): p. 1724.

7. Smolander, A. and V. Kitunen, Soil microbial activities and characteristics of dissolved organic $C$ and $N$ in relation to tree species. Soil Biology and Biochemistry, 2002. 34(5): p. 651-660.

8. Wang, X., J. Wang, and J. Zhang, Comparisons of three methods for organic and inorganic carbon in calcareous soils of northwestern China. PIOS one, 2012. 7(8): p. e44334.

9. Jones Jr, J.B., Laboratory guide for conducting soil tests and plant analysis. 2001: CRC press.

10. Singh, R. and S. Mishra, Available macro nutrients ( $N, P, K$ and $S)$ in the soils of Chiraigaon block of district Varanasi (UP) in relation to soil characteristics. Indian Journal of Scientific Research, 2012. 3(1): p. 97-100.

11. Rowell, D.L., Soil science: Methods \& applications. 2014: Routledge.

12. Methods Manual, Soil Testing in India. 2011.

13. Kelly, B., C. Allan, and B. Wilson, Corrigendum to: Soil indicators and their use by farmers in the Billabong Catchment, southern New South Wales. Soil Research, 2009. 47(3): p. 340-340.

14. Pathak, H. and D. Rao, Carbon and nitrogen mineralization from added organic matter in saline and alkali soils. Soil Biology and Biochemistry, 1998. 30(6): p. 695-702.

15. RP, S. and M. SK, Available macro-nutrients $(N, P, K$ and $S)$ in the soils of chiraigaon block of district Varansi(U.P.) in relation to soil Characteristics. Indian J Sci Res., 2012. 3(1): p. 97-100.

16. Bohn, H.L., D.G. Strawn, and G.A. O'Connor, Soil chemistry. 2015: John Wiley \& Sons. 
17. Bulgarelli, D., et al., Structure and functions of the bacterial microbiota of plants. Annual review of plant biology, 2013. 64: p. 807-838.

18. Wenke, K. and B. Piechulla, The Effects of Volatile Metabolites from Rhizobacteria on Arabidopsis thaliana, in Bacteria in Agrobiology: Crop Productivity. 2013, Springer. p. 379-400.

19. Chen, Y., et al., Sulfate removal and sulfur transformation in constructed wetlands: The roles of filling material and plant biomass. Water Research, 2016. 102: p. 572-581.

20. Maathuis, F.J. and E. Diatloff, Roles and functions of plant mineral nutrients. Plant Mineral Nutrients: Methods and Protocols, 2013: p. 1-21.

21. Essington, M.E., Soil and water chemistry: An integrative approach. 2015: CRC press.

22. Rousk, J., et al., Soil bacterial and fungal communities across a pH gradient in an arable soil. The ISME journal, 2010. 4(10): p. 1340-1351.

23. ADVIENTO-BORBE, M., et al., Soil greenhouse gas fluxes and global warming potential in four high-yielding maize systems. Global Change Biology, 2007. 13(9): p. 1972-1988.

24. Pietri, J.A. and P. Brookes, Relationships between soil $\mathrm{pH}$ and microbial properties in a UK arable soil. Soil Biology and Biochemistry, 2008. 40(7): p. 1856-1861.

25. Liu, L., et al., Interactive Effects of Nitrogen and Phosphorus on Soil Microbial Communities in a Tropical Forest. PLoS ONE, 2013. 8(4): p. e61188.

26. Wallenstein, M.D., et al., Nitrogen fertilization decreases forest soil fungal and bacterial biomass in three longterm experiments. Forest Ecology and Management, 2006. 222(1): p. 459-468.

27. Torsvik, V. and L. Øvreås, Microbial diversity and function in soil: from genes to ecosystems. Current opinion in microbiology, 2002. 5(3): p. 240-245. 